\title{
Expanding Higher Education in Taiwan: The Case of Doctoral Education
}

\author{
Chen-Wei Chang ${ }^{1} \&$ Wang-Ching Shaw ${ }^{1}$ \\ ${ }^{1}$ National Academy for Educational Research, Taiwan (R.O.C.) \\ Correspondence: Chen-Wei Chang, National Academy for Educational Research, Taiwan (R.O.C.), No. 2, \\ SanShu Road, Sanxia District, New Taipei City, 23703, Taiwan (R.O.C.). E-mail: \\ chenweichang@mail.naer.edu.tw
}

Received: August 10, 2015

Accepted: November 25, 2015 Online Published: December 8, 2015

doi:10.5539/hes.v6n1p1

URL: http://dx.doi.org/10.5539/hes.v6n1p1

\begin{abstract}
Higher education expansion is not a new development in the world. Different countries have faced various contexts and factors that push the expansion to occur. Since 1996, the Taiwanese government has allowed the private sector to open new higher education institutions or be upgraded for open more access at the higher education level to correspond to the general public's educational expectations. This article starts by describing the expansion of higher education from the elite to universal stage both globally and locally. The article then specifically introduces the case of the doctoral manpower structure in Taiwan and lists three specific scenarios regarding local $\mathrm{PhDs}$ ' reality in the current competitive job market, highlighting the further talent fault crisis in society today. In addition to discussing the consequences and challenges at the doctoral level of talent cultivation, the article further identifies the main issues facing the current manpower planning in Taiwan. The article calls for all stakeholders of the agenda to rethink the purpose of doctoral manpower cultivation in Taiwan over the long run.
\end{abstract}

Keywords: higher education expansion, manpower planning, doctoral education, Taiwan

\section{Introduction}

In recent decades, access to tertiary education has expanded remarkably, involving new types of institutions that offer more choices and new modes of delivery (OECD, 2008). The number of students attending colleges and universities around the world is growing at an explosive rate; university enrollment has grown from about 100 million in 2000 to 158 million in 2011 and is expected to reach 263 million by 2025 (Karaim, 2011; Guri-Rosenblit, Sebkova, \& Teichler, 2007).

In most western countries, student numbers started to increase rapidly at the end of the 1960s. American sociologist Martin Trow elaborated on three aspects of higher education growth: the rate of growth, change in the absolute size both of systems and institutions, and changes in the proportion of the relevant age cohort enrolled. Trow $(1973,2000)$ identified three phases in the evolution of the higher education: elite system (participation of fewer than $15 \%$ of the age group), mass higher education (participation between $15 \%$ and $50 \%$ ), and universal higher education (participation exceeding 50\%).

The expansion of education has clearly been involved in the extraordinary modern expansion of the professions and other formerly elite occupations. In addition, expanding access to and linking tertiary education to the demands in the labor market are vital steps to building a knowledge-based economy (OECD, 2014). Schofer and Meyer (2005) found that higher education expansion in countries was partly driven by broader rationales, like scientization, democratization, and the expansion of human rights. Economically and politically, countries with educated people and highly schooled elites could build a future out of expanded "human capital" to manage society rationally.

As a result, higher education systems have faced a challenge in accommodating the growth in student numbers in the existing higher education system and, further, in the job market. Therefore, this article uses the rapid expansion in Taiwan's higher education as a case to discuss the consequences. In addition, the oversupply of doctorate manpower in society generates discussion among the public. A doctoral degree used to be an honor in Taiwanese society; today it has become a burden. This article tries to unveil the consequences and challenges 
that Taiwanese society is facing since the higher education expansion in order to bring attention to the relevant stakeholders' beliefs about the further possibility of improving the current condition.

\section{Universal Access at the Higher Education Level in Taiwan}

In order to meet the needs of society and fulfill the political pledge of "a national university in every county", Taiwan's Ministry of Education led the expansion in the number of colleges and universities by upgrading junior colleges and building new universities in Taiwan, raising the total number of Higher Education Institutions (HEIs) from 105 in 1984 to 159 in 2014 (see Table 1), a period of just 30 years. The growth stems mostly from upgraded HEIs. In 1984, Taiwan had only 16 universities; this number increased to 124 by 2014-a greater than sevenfold increase in 30 years. During the same period, the number of students at the higher education level also increased, growing from 412,381 to $1,339,848$ (see Table 2), representing a $325 \%$ increase. The graduate school level witnessed an 18-time increase in master's degree students and a 20-time increase in doctoral students, suggesting a very rapid expansion of higher education, which can be attributed to the educational reform in Taiwan's post-authoritarian era, especially since the 1990s (MOE, 2015). This expansion of Taiwan's higher education system, in terms of both the number of universities and the size of the student population, marks a turn in Taiwan's higher educational policy from one focused on elite education to one striving for universal education, according to Trow's (1974) classification of the higher education system.

Table 1. Number of higher education schools, 1994 to 2014

\begin{tabular}{|c|c|c|c|c|c|c|c|c|}
\hline \multirow[t]{3}{*}{ School Year } & \multicolumn{2}{|c|}{ Junior college } & \multicolumn{2}{|l|}{ College } & \multicolumn{2}{|c|}{ University } & \multicolumn{2}{|c|}{ Total Number } \\
\hline & \multicolumn{2}{|c|}{77} & \multicolumn{2}{|c|}{12} & \multicolumn{2}{|c|}{16} & \multicolumn{2}{|c|}{105} \\
\hline & Public & Private & Public & Private & Public & Private & Public & Private \\
\hline & 21 & 56 & 6 & 6 & 9 & 7 & 36 & 69 \\
\hline \multirow[t]{3}{*}{1994} & \multicolumn{2}{|c|}{72} & \multicolumn{2}{|c|}{35} & \multicolumn{2}{|c|}{23} & \multicolumn{2}{|c|}{130} \\
\hline & Public & Private & Public & Private & Public & Private & Public & Private \\
\hline & 13 & 59 & 17 & 18 & 15 & 8 & 45 & 85 \\
\hline \multirow[t]{3}{*}{2004} & \multicolumn{2}{|c|}{14} & \multicolumn{2}{|c|}{70} & \multicolumn{2}{|c|}{75} & \multicolumn{2}{|c|}{159} \\
\hline & Public & Private & Public & Private & Public & Private & Public & Private \\
\hline & 3 & 11 & 17 & 53 & 34 & 41 & 54 & 105 \\
\hline \multirow[t]{3}{*}{2014} & \multicolumn{2}{|c|}{14} & \multicolumn{2}{|c|}{21} & \multicolumn{2}{|c|}{124} & \multicolumn{2}{|c|}{159} \\
\hline & Public & Private & Public & Private & Public & Private & Public & Private \\
\hline & 2 & 12 & 1 & 20 & 48 & 76 & 51 & 108 \\
\hline
\end{tabular}


Table 2. Number of students in higher education institutions, 1984 to 2014

\begin{tabular}{|c|c|c|c|c|c|c|c|c|c|c|}
\hline \multirow[t]{2}{*}{ School Year } & \multicolumn{10}{|c|}{ Higher Education Institutions } \\
\hline & \multicolumn{2}{|c|}{ Associate Degree } & \multicolumn{2}{|c|}{ Bachelor's Degree } & \multicolumn{2}{|c|}{$\begin{array}{c}\text { M.A. } \\
\text { Degree }\end{array}$} & \multicolumn{2}{|c|}{$\begin{array}{c}\text { Ph.D. } \\
\text { Degree }\end{array}$} & \multicolumn{2}{|c|}{ In Total } \\
\hline \multirow[t]{3}{*}{1984} & 227,492 & & 173,908 & & 9,481 & & 1,500 & & 412,381 & \\
\hline & Public & Private & Public & Private & Public & Private & Public & Private & Public & Private \\
\hline & 54,372 & 173,120 & 65,857 & 108,051 & 6,880 & 2,601 & 1,185 & 315 & 212,102 & 200,279 \\
\hline \multirow[t]{3}{*}{1994} & 378,860 & & 302,093 & & 30,832 & & 8,395 & & 720,180 & \\
\hline & Public & Private & Public & Private & Public & Private & Public & Private & Public & Private \\
\hline & 60,289 & 318,571 & 126,913 & 175,180 & 22,574 & 8,258 & 7,464 & 931 & 217,240 & 502,940 \\
\hline \multirow[t]{3}{*}{2004} & 230,938 & & 894,528 & & 135,992 & & 24,409 & & $1,285,867$ & \\
\hline & Public & Private & Public & Private & Public & Private & Public & Private & Public & Private \\
\hline & 22,567 & 208,371 & 238,746 & 655,782 & 88,072 & 47,920 & 20,504 & 3,905 & 369,889 & 915,978 \\
\hline \multirow[t]{3}{*}{2014} & 99,270 & & $1,037,062$ & & 172,968 & & 30,549 & & $1,339,848$ & \\
\hline & Public & Private & Public & Private & Public & Private & Public & Private & Public & Private \\
\hline & 11,214 & 88,056 & 283,854 & 753,208 & 115,205 & 57,763 & 24,382 & 6,167 & 434,654 & 905,194 \\
\hline
\end{tabular}

Source: Authors, using data from the Ministry of Education (2015). Retrieved from http://www.edu.tw/pages/detail.aspx?Node=4075\&Page=20046\&Index $=5 \& W I D=31 \mathrm{~d} 75 \mathrm{a} 44-$-efff-4c44-a075-15a 9eb7aecdf

In a universal system, social justice refers not to the accessibility of higher education as such, but the accessibility of higher education with certain characteristics, produced within different kinds of institutions. The question is not "access", but rather "access to what?" This question is currently being asked in North America, Europe, Asia, and Russia (Bastedo \& Gumport, 2003; Eggins, 2010; Smolentseva, 2012). If we look closely at the expansion of different sectors of the higher education system in Taiwan, private HEIs have grown much faster than public ones in terms of both the number of schools and their graduates. As shown in Table 1, between 1984 and 2014, the number of public universities and colleges increased 3.27 times, compared to 7.38 times in the private sector. This discrepancy in expansion is also evident in the composition of the entire undergraduate body. The proportion of undergraduates from private universities and colleges jumped from $70.05 \%$ to $74.03 \%$ in 30 years, while the number of undergraduates increased about 6.97 times during the same period (see Table 2).

\section{Expanding Up: Growth of Enrollment at Graduate Schools}

UNESCO's (2014) observation of the global expansion at the undergraduate level indicated that one consequence of expanding undergraduate enrollment was an accelerated demand for qualified instructional staff. This demand emerged from two sources. First, the proliferation of higher education institutions created a demand for more instructors. Hence, the need to prepare college and university instructors to fill new openings and to upgrade those already in the system created a substantial demand for graduate preparation programs (UNESCO, 2014). At the same time, governments expressed a new interest in the role of universities as the centers of research and innovation that would accelerate national economic development. As university-based research is generally conducted within graduate programs and typically utilizes graduate students as research assistants, governments recognize that a national investment in graduate education could help countries meet the demand for qualified instructors at the undergraduate level while also meeting the national demand for more scientific research (UNESCO, 2014).

In addition, doctoral level research plays a crucial role in driving innovation and economic growth and contributes significantly to the national and international knowledge base. Therefore, many OECD countries invest heavily in providing doctoral level education (Halse \& Mowbray, 2011; Smith, 2010), and individuals who attain this level of education benefit from higher wages and higher employment rates (OECD, 2014). Although doctorates represent only a small proportion of tertiary programs, the graduation rate from these programs has doubled from $0.8 \%$ in 2000 to $1.6 \%$ in 2012 (OECD, 2014). 


\section{Graduate Students' Expansion in Taiwanese Context}

Corresponding to the public's request for expanded access at the higher education level in Taiwan, the MOE adopted "the enrollment's total amount control policy" in 2002, which allowed colleges and universities to arrange the programs, classes, and numbers of students under the control of the total amount, responding to each school's developing vision and manpower demand structure in society. However, the $\mathrm{PhD}$ programs are excluded from this policy and need to be further examined by the MOE before they can be set up or expanded. Similar to UNESCO's indication, the expanding undergraduate body in Taiwan pushed the graduate level expansion, which required more qualified faculty to teach and serve, especially at the doctoral level. As shown in Table 2, in 1984, 1,500 doctoral students attended graduate schools, accounting for $0.36 \%$ of the student population in the higher education system. In 2014, 30,549 doctoral students attended these programs, demonstrating an approximately 20 -time increase over the 1984 numbers. In addition, the number of doctoral students represented $2.28 \%$ of the total population at the higher education level in 2014. The number of doctoral programs grew from 498 in 2001 to 839 in 2013, with 341 of these 839 being newly established (MOE Department of Statistics, 2014). Such rapid expansion has called the doctoral program's establishment and evaluation into questioned.

An additional factor contributed to the expanding phenomenon at graduate schools. The Taiwanese hold one value very dearly: education is the way to break through destiny and to improve original Social Economic Status (SES). The most famous example is that the previous President Shui-Bian Chen, who was born to one of the poorest families in a rural area in southern Taiwan. President Chen worked hard and went on to earn a bachelor's degree from a top university, thereby giving him a good break from the limitations of his background. As there is nearly no limit for individuals to access higher education and even advanced degrees, people try their best to study for long as possible.

When it comes to a universal higher education system, the Taiwanese are trying to increase their expectations in terms of access to graduate school. One study tracked 256,000 college graduates' next steps in 2008 . The results indicated that $41.7 \%$ of graduates planned to pursue a master's degree and $8.6 \%$ planned to pursue a doctoral degree. The research showed that individuals' motivation to pursue advanced degrees, including master's and doctoral degrees, is very high in Taiwan. However, the research pointed out that motivation for these Taiwanese degree pursuers stemmed from degrees being "easy to get"; they did not care if it is worth investing their money and time in or if the degree guarantees a decent job after school (Chen, 2011).

\section{After Graduation: Insufficient Corresponding Positions for Graduates with Higher Education Degrees}

During the process of expanding global higher education, the world's job market has changed dramatically to become a knowledge economy. At the same time, the world has been facing an economic recession, leaving fewer job vacancies to make the school-to-work transition substantially more difficult for young people, as those with more work experience are favored over new entrants into the labor market (OECD, 2014).

\section{Too Many Graduates, Overcrowded Job Market in Real World}

As $\mathrm{Wu}$ (2011) mentioned, the global economic recession in combination with the excessive number of graduates has led to a high graduate unemployment rate and a competitive labor market. Recent higher education graduates from both developed and developing countries have experienced this situation, leading to the so-called "overeducation" and "crowding-out" problems (Dolado, Felgueroso, \& Jimeno, 2000; Mayhew, Deer, \& Dua, 2004; Tomlinson, 2008). Accepting traditionally non-graduate occupations implies that college graduates are lowering their job expectations and their rate of return for higher education degrees. Unemployment seems to hit the younger generations hardest. Across OECD countries, unemployment rates are higher among younger adults than among older adults at all levels of education. The gap between the two age groups is smallest among tertiary-educated adults: $7 \%$ of younger adults in this group are unemployed compared to $4 \%$ of older adults. This indicates the growing importance of attaining a tertiary education (OECD, 2014).

The unemployment rate in Taiwan shows part of the difficult reality for finding an "appropriate job". Taiwanese government statistics reveal that, since 2006, the unemployment rate of individuals with a college or postgraduate degree has exceeded the unemployment rates of those at all other educational levels, rising from $2.63 \%$ in 1997 to $5.62 \%$ in 2010 . Although the unemployment rate dropped to $4.99 \%$ in 2014 , it is still highest compared to those at all other educational levels (Executive Yuan, 2015).

The increase in the number of doctoral graduates and programs has also affected the purposes of the doctorates' and graduates' employment pathways. No longer is procuring an academic position the sole reason for, or outcome of, doctoral study. In the UK, only approximately $35 \%$ of $\mathrm{PhD}$ graduates are employed in a research role (Thomson \& Walker, 2010), and $50 \%$ of EU and $70 \%$ of USA doctoral graduates work outside of academe 
in both research and non-research positions (Borrell-Damien, 2009; Council of Graduate Schools, 2008).

\section{Are Positions Created for PhDs?}

\section{What PhDs expect to receive after earning their degrees?}

Doctoral education is, for the most part, still structured as if it were meant to prepare students for life as university professors - as if times have not changed and graduate students have remained the same (Nerad, 2009). As Nerad (2009) pointed out, assumptions related to PhD degrees and employment include that "all students who study for a $\mathrm{PhD}$ want to become/and should become professors; professorial positions are highly desirable, and the best doctoral recipients become professors; the career paths of these PhDs are linear and smooth traditional academic careers, moving from $\mathrm{PhD}$ completion to assistant professor, with perhaps two years of postdoctoral fellowship in between, then to associate professor, and on to full professor".

\section{What PhDs really do?}

Although the historical view, as shown in Nerad's (2009) comments, puts forth that the doctorate is preparation for an academic career and $\mathrm{PhD}$ graduates move into academic positions, doctoral students' expectations might not be in accord with this assumption. A national study conducted by Neumann (2003) on doctoral education showed that only around half of doctoral candidates necessarily contemplated moving into an academic career. This was reinforced by a follow-up multi-year institutional case study of new doctoral students (Neumann, 2006). The survey results from the UK, Canada, and France showed that approximately half of the nation's doctoral graduates are employed in the higher education sector, with the majority working in academic positions involving both teaching and research (Giret, 2005; Haynes, Metcalfe, \& Videler, 2009; King, 2008). However, taking a longer-term perspective, the common trend from the mid 1990s shows declining proportions of doctoral graduates employed in academic positions, whether in Germany (Enders, 2004), France (Paul \& Perret, 1999), the United States (Council of Graduate Schools, 2007), or Australia (Australia Research Council, 1999; Neumann, Kiley, \& Mullins, 2008).

A consistent survey finding is that fewer than half of all US doctoral graduates from research-intensive universities pursue academic careers. There are variations by disciplines, with only one-third of science and engineering graduates pursuing academic careers, compared to two-thirds of English, mathematics, and political science graduates. Importantly, only around half of doctoral students even aspire to build an academic career. Compounding this fact is that doctoral programs and universities lack career development information and guidance (Nerad, 2004; Rudd, Morrison, \& Picciano, 2008), and this pattern is not restricted to the PhD program or to the U.S. (Larkin \& Neumann, 2009a, 2009b). Indeed, these findings are echoed in an Australian study (University of Queensland Social Research Centre, 2007) of doctoral graduate employment and careers from eight research-intensive universities 5 to 7 years after completing their PhDs. Within the Australian study, almost half of the doctoral graduates worked in higher education, with graduates from the humanities and social sciences being more likely to have a career within the university sector. The study findings do not, however, distinguish between academic, research, and administrative/management occupations within the higher education sector (Neumann \& Tan, 2011).

In Taiwan, the number of newly graduated doctoral students increased from 117 in 1983 to 4,048 in 2013, increasing approximately 35 times (see Table 3). In addition, approximately half of $\mathrm{PhD}$ holders spend 4 to 6 years earning their degrees, and $30 \%$ of $\mathrm{PhD}$ holders earn their degrees in 6 to 7 years. After PhD students complete their studies and start to work, they also expect to receive good monetary rewards. However, the new $\mathrm{PhD}$ holder earns only 5,000 NTD more than the average salary in Taiwan. If he/she chooses to work after receiving his/her master's degree, the yearly bonus salary for 2 to 5 years of work experience is increases by at least 5,000 NTD (Next Magazine, 2013). PhDs invest much money and time in pursuing their degrees and expect to work at a decent position. However, the real situation for PhDs in finding decent jobs that pay well is like a dream that never comes true. 
Table 3. Number of higher education graduates, 1983 to 2013

\begin{tabular}{|c|c|c|c|c|c|}
\hline \multirow{2}{*}{$\begin{array}{l}\text { School } \\
\text { Year }\end{array}$} & \multicolumn{5}{|c|}{ Higher Education Institutions } \\
\hline & $\begin{array}{c}\text { Associate } \\
\text { Degree }\end{array}$ & $\begin{array}{c}\text { Bachelor's } \\
\text { Degree }\end{array}$ & M.A. Degree & $\begin{array}{l}\text { Ph.D. } \\
\text { Degree }\end{array}$ & In Total \\
\hline 1983 & 46,227 & 35,716 & 2,849 & 117 & 84,909 \\
\hline 1993 & 98,433 & 63,160 & 10,448 & 808 & 172,849 \\
\hline 2003 & 91,009 & 192,854 & 35,981 & 1,964 & 321,808 \\
\hline 2013 & 18,240 & 228,762 & 59,991 & 4,048 & 311,041 \\
\hline
\end{tabular}

The job market for doctoral students in Taiwan, as Nerad (2009) mentioned in his research, is more of a "one-destination" journey. Although industrial and electronic fields indeed need R\&D engineers with $\mathrm{PhD}$ degrees, $\mathrm{PhD}$ graduates in the fields of social science and humanities still plan to be professors at HEIs. The supply-demand structure of the $\mathrm{PhD}$ job market in Taiwan is summarized in Table 4, which shows that the demand side for PhDs is more controlled than the supply side, which might cause $\mathrm{PhD}$ graduates to end up with no job in society.

Table 4. Job market supply and demand for PhDs in Taiwan

\begin{tabular}{ll}
\hline Supply & Demand \\
\hline $\begin{array}{l}\text { Faculty from those closed/closing departments } \\
\text { and HEIs }\end{array}$ & Faculty positions from retirement \\
$\begin{array}{l}\text { New PhDs from local and foreign doctoral } \\
\text { programs }\end{array}$ & $\begin{array}{l}\text { New establishment of departments/research } \\
\text { centers/graduate schools (programs) }\end{array}$ \\
$\begin{array}{ll}\text { The current postdocs and contract faculty } \\
\text { Teaching positions } \\
\text { programs/centers/departments relevant to or } \\
\text { irrelevant to PhD students'specialty }\end{array}$ \\
$\begin{array}{ll}\text { Faculty who currently have official contract at } \\
\text { HEIs }\end{array}$ \\
\hline
\end{tabular}

Source: Authors.

The National Applied Research Laboratories' (R.O.C.) survey focused on PhDs in 2014 found that three-fourths of 52,960 participating PhD students are currently working at HEIs or in the educational sectors (see Table 5), the expected destinations for PhDs. 
Table 5. Distribution of numbers of PhDs from various HEIs and their current serving agencies, 2014

\begin{tabular}{|c|c|c|c|c|c|c|c|c|}
\hline \multirow{3}{*}{$\begin{array}{l}\text { Current } \\
\text { Serving } \\
\text { Agency } \\
\text { Graduate HEIs }\end{array}$} & \multirow{3}{*}{ Education } & \multirow{2}{*}{\multicolumn{2}{|c|}{ Government }} & \multirow{3}{*}{$\begin{array}{l}\text { Private } \\
\text { NPOs }\end{array}$} & \multirow{3}{*}{ Industry } & \multirow{3}{*}{ NGOs } & \multirow{3}{*}{ N/A } & \multirow{3}{*}{$\begin{array}{l}\text { In } \\
\text { Total }\end{array}$} \\
\hline & & & & & & & & \\
\hline & & Administ-ration & Research & & & & & \\
\hline \multirow{2}{*}{ Local public HEIs } & 18,062 & 1,256 & 3,331 & 360 & 2,817 & 5 & 28 & 25,859 \\
\hline & $45.2 \%$ & $59.5 \%$ & $58.9 \%$ & $37.2 \%$ & $66.8 \%$ & $33.3 \%$ & $49.1 \%$ & $48.8 \%$ \\
\hline \multirow{2}{*}{$\begin{array}{l}\text { Local } \\
\text { HEIs }\end{array}$} & 3,045 & 264 & 252 & 227 & 341 & 1 & 8 & 4,138 \\
\hline & $7.6 \%$ & $12.5 \%$ & $4.5 \%$ & $23.5 \%$ & $8.1 \%$ & $6.7 \%$ & $14.0 \%$ & $7.8 \%$ \\
\hline \multirow{2}{*}{ Foreign HEIs } & 18,456 & 551 & 1,796 & 352 & 955 & 9 & 19 & 22,138 \\
\hline & $46.2 \%$ & $26.1 \%$ & $31.8 \%$ & $36.4 \%$ & $22.6 \%$ & $60.0 \%$ & $33.3 \%$ & $41.8 \%$ \\
\hline \multirow{2}{*}{$\begin{array}{l}\text { China, Hong } \\
\text { Kong, or Macao } \\
\text { HEIs }\end{array}$} & 321 & 12 & 40 & 5 & 48 & 0 & 0 & 426 \\
\hline & $0.8 \%$ & $0.6 \%$ & $0.7 \%$ & $0.5 \%$ & $1.1 \%$ & $0.0 \%$ & $0.0 \%$ & $0.8 \%$ \\
\hline \multirow{2}{*}{ N/A } & 48 & 29 & 237 & 24 & 59 & 0 & 2 & 399 \\
\hline & $0.1 \%$ & $1.4 \%$ & $4.2 \%$ & $2.5 \%$ & $1.4 \%$ & $0.0 \%$ & $3.5 \%$ & $0.8 \%$ \\
\hline In Total & 39,932 & 2,112 & 5,656 & 968 & 4,220 & 15 & 57 & 52,960 \\
\hline
\end{tabular}

\section{Special Scenarios for PhD Holders in Taiwan}

This section of the paper describes the three specific scenarios regarding the real conditions that $\mathrm{PhD}$ holders experience in Taiwan, including jobless $\mathrm{PhDs}$, PhDs without decent jobs, and the ongoing expanding $\mathrm{PhDs}$ in the field of education.

\section{Jobless PhD Holders}

Here, "jobless PhDs" refers to those PhD holders who experience the transition from school to work as "on the way to finding a permanent job" process. In Taiwan, it is a simple and linear job-seeking process for $\mathrm{PhD}$ holders. Huang (2010) explained that, "those having master's degrees would teach at junior colleges, [while] those PhDs would teach at HEIs after graduation". According to the National Science Council' published data from 2002, $89 \%$ of $\mathrm{PhD}$ holders worked full time, and nearly $70 \%$ of them worked in the education sectors, such as teaching at HEIs. At that time, PhD holders' annual income was about 1 million to 1.5 million NTD. In addition, $65 \%$ of $\mathrm{PhD}$ holders considered their work to be closely relevant to what they had learned in school. Overall, in 2002, only $0.7 \%$ of $\mathrm{PhD}$ holders were "jobless" (Han \& Lin, 2007).

However, $\mathrm{PhD}$ holders no longer experience such a smooth transition from school to work nowadays. Currently, approximately 34,000 doctoral students are attending HEIs. If all of them could graduate from school in 6 years, an average 5,625 $\mathrm{PhD}$ holders would be produced from the supply side annually. However, this accounting excludes those $\mathrm{PhD}$ holders who graduated in the past few years who are still seeking permanent job positions. From the demand side at HEIs, if 2,800 faculty positions were released each year, approximately $50 \%$ of $\mathrm{PhD}$ holders would need to find jobs outside of HEIs (Chen, 2010).

The calculations between the demand and supply sides, as in the preceding paragraphs, are actually too optimistic. As one recently graduate $\mathrm{PhD}$ holder in history said after his nine years of doctoral study, "the number of students at HEIs is shrinking, which affects financial condition for HEIs to hire new faculty after senior professors retire from schools. At the same time, the pressure from higher education evaluation makes private HEIs hurriedly retire faculty members from public schools, which also hinders new $\mathrm{PhD}$ holders' careers" (Lin, 2009). In such a job-seeking process, recently graduated $\mathrm{PhD}$ holders might be frustrated with their passion for research and teaching, which also wastes national resources that have been put into preparing doctoral manpower. 
At the same time, getting faculty positions at local HEIs is a very competitive process. One president of a private HEI said, "we have opened 11 faculty positions this year, and there were almost $100 \mathrm{PhD}$ applicants. Two-thirds of the final $11 \mathrm{PhDs}$ graduated from the top doctoral programs abroad, and the rest of professors are from the best public HEIs in Taiwan". This president pointed out that PhD holders who graduated from private HEIs in Taiwan find it very hard if not impossible to get offers from HEIs locally (Han \& Lin, 2007).

\section{PhD Holders without Decent Jobs}

If the current job market for local $\mathrm{PhD}$ holders is so competitive, where do these graduates go? In Taiwan, a hot topic reported by a journalist and posted in mass media in 2013 was "PhD sells fried chicken chops". The story started when a PhD student gave up his doctoral studies and started to sell fried chicken chops back in his hometown. His story initiated a public discussion about there being too many $\mathrm{PhD}$ holders in Taiwan. In addition, the public indicated that as a "PhD-to-be", he is overeducated for such jobs in night markets. Overall, the phenomenon of "PhD sells fried chicken chops" refers to $\mathrm{PhD}$ holders who give up their "academic work track" to find "alternative jobs". The PhD student in this story mentioned that "holding a $\mathrm{PhD}$ degree is not a guarantee for a 'matching' job in Taiwan. I left the expected track and started to sell fried chicken chops in the night market to make a living. If there would be other PhDs or $\mathrm{PhD}$ students could not see their future, I welcome them to join my "business"” (Chen \& Chen, 2013).

Most students who study in doctoral programs decided to pursue such a degree. If they fail to complete the degree and take another career path, it might result in them wasting their time and money while wasting the investment from the school and society as a whole. If a doctoral program could lead a "PhD to be" to a decent job, who would want to sell fried chicken chops in the night market? Although the public believes that there are too many $\mathrm{PhD}$ holders in society, the gap between how school prepares those PhDs and what the job market expects from them should be the real issue (Tssdnews, 2013).

\section{PhD Holders in the Field of Education}

In the last 20 years, higher education has continued to expand, with 379 newly established departments at the undergraduate level, 302 master's programs, and 103 doctoral programs. This is mainly because of the development of new industries, deeper professional divisions, and the changing manpower structure in Taiwan, which affect the demand and supply for higher qualified human capital (MOE Department of Statistics, 2014). In particular, student enrollment in doctoral programs in the field of education has grown the fastest at the doctoral level, which might be because currently employed teachers go back to school to study and even pursue $\mathrm{PhD}$ degrees (MOE Department of Statistics, 2014).

\section{- Policy reform expanded the demand for PhDs in the field of education}

The main reason behind the expansion of the number of PhDs in the field of education is the teacher education reforms in 1994. Prior to 1994, primary and high school teachers received their education at 4 universities and 7 colleges, all of which were preparing future teachers. In February 1994, the Teacher Education Act was announced, and the Policy of Polybasic Teacher Cultivationallowed all kinds of HEIs to initiate their own teacher education programs to prepare K-12 teachers (MOE, 2014). Therefore, since 1995, many public and private HEIs have applied to open teacher education programs, which needed to hire qualified faculty with $\mathrm{PhDs}$ in education. Corresponding to this demand, universities with a teacher education center or department of education and those without such specialties sought to open doctoral programs in the field of education to satisfy the demand. In 1994, the number of doctoral students in the field of education was 286 and the number of PhD holders in the field was only 34 . By 2013, these numbers had grown to 2,634 and 328, respectively (Table 6), marking an approximately tenfold increase in the field of education at the higher education level in about 30 years. 
Table 6. Number of doctoral students and graduated PhD holders in the field of education, 1998 to 2013

\begin{tabular}{|c|c|c|c|c|c|c|}
\hline \multirow{3}{*}{ Year } & \multicolumn{3}{|c|}{ Doctoral Students } & \multicolumn{3}{|c|}{$\mathrm{PhDs}$} \\
\hline & \multirow[t]{2}{*}{ All Fields } & \multicolumn{2}{|c|}{ Education } & \multirow[t]{2}{*}{ Total } & \multicolumn{2}{|c|}{ Education } \\
\hline & & Number & Ratio & & Number & Ratio \\
\hline 1994 & 8,395 & 286 & 3.40 & 848 & 34 & 4.01 \\
\hline 1998 & 10,845 & 571 & 5.26 & 1,282 & 70 & 5.46 \\
\hline 2002 & 18,705 & 1,148 & 6.14 & 1,501 & 93 & 6.20 \\
\hline 2006 & 29,839 & 1,913 & 6.41 & 2,614 & 176 & 6.73 \\
\hline 2010 & 34,178 & 2,540 & 7.43 & 3,705 & 223 & 6.02 \\
\hline 2013 & 31,475 & 2,634 & 8.37 & 4,241 & 328 & 7.73 \\
\hline
\end{tabular}

Source: Authors, using data from the Ministry of Education (2015). Retrieved from http:/www.edu.tw/pages/detail.aspx?Node $=4075 \&$ Page $=20046 \& I n d e x=5 \& W I D=31 \mathrm{~d} 75 \mathrm{a} 44-\mathrm{efff}-4 \mathrm{c} 44-\mathrm{a} 075-15 \mathrm{a}$ $9 \mathrm{eb} 7 \mathrm{aecdf}$

\section{- $\quad$ Are there enough positions for local PhD holders?}

Obviously, there are not enough vacant positions for $\mathrm{PhD}$ holders in education give the many local $\mathrm{PhD}$ students who graduate each year in Taiwan. Thus, in the first few years after the Policy of Polybasic Teacher Cultivation was announced, the demand was not as great as the supply of PhDs in the field of education. The low birth rate in Taiwan in recent years decreased the K-12 teacher recruitment and led to the further shut down 44 teacher education programs in 20 years (MOE, 2013). When the programs shut their doors to students, the programs also fired faculty members or relocated them to other programs, which further pressured recent $\mathrm{PhD}$ graduates and doctoral students in the field of education more than their earlier peers.

As shown in Table 6, at least 300 doctoral students in the field of education have graduated in recent years, including graduates from local and foreign HEIs. However, the local HEIs prefer to hire foreign doctorate holders (Note 1), as mentioned in the section on jobless doctorate degree holders. The authors checked 23 departments of education (Note 2) that offer doctoral programs to inquire about the country of distribution of their full-time faculty members' $\mathrm{PhDs}$ in 2015 . We found that more faculty members from these programs had foreign $\mathrm{PhD}$ degrees. In particular, even fewer programs hired their own program graduates (see Table 7). Overall, the job market in the higher education system in the field of education is not friendly to locally educated $\mathrm{PhD}$ holders.

Table 7. Faculty members awarded doctoral degrees at 23 public HEIs

\begin{tabular}{ll}
\hline Faculty Members' Doctoral Degree & Number \\
\hline Foreign PhDs & 195 \\
Local PhDs & 128 \\
Program PhDs & 32 \\
\hline
\end{tabular}

Source: Authors, organized by checking 23 HEIs' full-time faculty members' PhD degrees by country.

\section{Rethinking the Future for Doctoral Education in Taiwan}

The three scenarios depict the development of doctoral education in Taiwan. Here, the authors discuss the current challenges facing talented people in education at the doctoral level in Taiwan by asking the following three questions.

Have doctoral degrees been devalued just because of the rapid expansion of the doctoral programs?

The expanding numbers of doctoral degrees/programs and the recruitment of talented students show the open access to advanced degrees in Taiwan. They not only indicate the democratic values through the reform, but encourage the general public to pursue their dreams through education. However, the situation became a nightmare when these recent $\mathrm{PhD}$ graduates entered the job market, which offered only a few positions. If we look further into this reality, the policy maker, the HEIs, and the new PhD graduates have played their own roles 
in creating the current phenomenon. The policy maker opens the door for activating doctoral programs corresponding to the public's expectations for higher education. The HEIs happily accepted the permission to open their own doctoral programs not only to build their reputations, but also to make or save money through doctoral students' hard work in labs and their advisors' projects. As for new $\mathrm{PhD}$ graduates during this period, their dreams come true as they earn their $\mathrm{PhD}$ degrees at the end of their studies. In such a depiction, the situation seems to be a harmonious picture. However, the harmonious picture is ruined by the characters in the picture, including the careless policy maker who opened the doors without considering the purpose of doctoral education and the manpower structure on the demand side. At the same time, the rapidly opened doctoral programs in HEIs served more functions, such as using the doctoral students as assistants to conduct research and to teach, rather than for nurturing the future talented manpower in the fields. For the individual $\mathrm{PhD}$ seeker, he/she assumes that the highest degree in the education system should bring monetary rewards from a decent position. The unclear vision of such a policy created a series of consequences without easy solutions.

If the local HEIs prefer to hire foreign PhD holders, what's wrong with the local doctoral education?

When the new $\mathrm{PhD}$ graduates mentioned that their training in doctoral programs did not fully equip them for the current employment and job market, it not only related to the issue of devaluing degrees. It also related to the quality of education that doctoral programs provided for their students. As mentioned earlier in this article, the evaluation of doctoral programs is questioned, mainly because the requirements for HEIs seeking to open new doctoral programs basically focused on how many faculty members are hired for the program and how many "good papers" each faculty member publishes every year, not how comprehensive the program is for future students.

Second, HEIs preferred to hire foreign PhD holders as teachers because doing so could help them build better reputations. It is like a vicious circle, which starts with the expansion of HEIs, the need for more qualified faculty members, and culminating in too many $\mathrm{PhD}$ holders; as a result, the structure is imbalanced, with supply being greater than demand. Foreign $\mathrm{PhD}$ holders, compared to local $\mathrm{PhD}$ holders, sound better due to the reputations based on their famous and historical schools in other countries. Thus, foreign PhD holders are even more competitive in the job market. Thus, ultimately, local $\mathrm{PhD}$ holders are produced, but not preferred in the job market.

Although it might be biased for HEIs to prefer foreign PhD holders to local ones, the real issue is the quality of local doctoral programs being questioned by employers. The new doctoral programs have limited resources, in terms of both software and hardware, making their students less appealing than those from historical programs locally in the same field. For example, very few of the local $\mathrm{PhD}$ holders graduated from more recently established doctoral programs were hired by their programs in the 23 HEIs depicted in Table 7.

Expanding doctoral programs now is lead to zero applicants. What's next for doctoral manpower planning in Taiwan?

According to the latest news regarding student recruitment at the doctoral level, 36 programs at 19 HEIs had zero enrollment in 2014 (MOE Department of Statistics, 2015). The PhD degree itself once used to be the motivation for students to pursue a better future, but now seems to be an obstacle for its holders in finding an appropriate job. Therefore, even the best HEIs' doctoral programs cannot attract local talented people to apply, much less admit. To address this situation, the MOE announced that enrollment numbers at higher education levels will be reduced from 301,820 undergraduate students in 2003 to 182,293 in 2023. The number of doctoral students will be reduced from 7,670 in 2003 to 4,800 in 2023, leading to an approximately $37 \%$ reduction (MOE, 2015). However, is reducing the number of students at the higher education level the solution? Dr. Yang, the president of National Sun Yat-Sen University, pointed out that there has been a reducing number of doctoral applicants (Chen \& Wang, 2015). If the trend continues, Dr. Yang predicted that Taiwan will face a temporary shortage of trained personnel to replace the older generation in 5 to 10 years (UDN, 2015). The director-general at the Department of Higher Education mentioned that, since the lower birth rate and student enrollment number have been reduced in recent years, the faculty positions at HEIs have become less available. Therefore, the government plans to initiate academic-track programs to recruit real elite offering a full governmental scholarship and requiring the receivers to complete the program within a certain time period (UDN, 2015). However, this MOE-proposed plan might not be a sufficient solution for the current talent cultivation crisis in Taiwan. Taiwan will need to carefully consider the manpower structure of each industry in the society first and further plan to cultivate the reasonable numbers of local doctoral manpower. Furthermore, it is crucial to reexamine the program design to prepare local $\mathrm{PhD}$ holders in every field to ensure the close connection between what is taught and what is needed in the field both locally and globally. Moreover, the local PhD holders should 
also play their roles with competitive knowledge and ability to not only compete for the limited open positions at HEIs, but also create their own positions using their professional skills to make their own contributions to society.

\section{Concluding Remarks}

The global expansion of higher education has brought the knowledge economy to an advanced level and is benefitting the local society as a whole. However, the expansion process puts $\mathrm{PhD}$ holders in an even more competitive job market nowadays. The manpower planning in society should overall be considered in light of national manpower demands and individual fulfillment. In Taiwan, the careless practices when expanding the doctoral education resulted in the number of doctoral programs and students increasing too rapidly. Compared to the decreasing faculty positions, too many local $\mathrm{PhD}$ holders have experienced frustration and consequently discouraged people from pursuing $\mathrm{PhD}$ degrees, which might create a talent gap in the near future according to the chief of administrative committee's comments (Wang, 2012). The Taiwanese case shows a hasty policy-making process that ruined the original system of demand and supply for PhDs and even destroyed the Chinese dreams of how "education can change people's original SES". Destruction is much easier than the reconstruction of values and beliefs in society. Further steps for manpower planning in Taiwan are more crucial than ever for rebuilding the public's trust in the government and starting a new future for local PhD holders to contribute their talents to the local and global societies.

\section{References}

Australian Research Council. (1999). Career paths for PhD graduates: A scoping study. Prepared by the Graduate Careers Council of Australia. Canberra: ARC.

Bastedo, M., \& Gumport, P. (2003). Access to What? Higher Education, 46(3), $341-359$. http://dx.doi.org/10.1023/A:1025374011204

Borrell-Damien, L. (2009). Collaborative doctoral education: University-industry partnerships for enhancing knowledge exchange. Report for European University Association. Brussels: European University Association.

Chen, C. H. (2011). PhDs are oversupplied in Taiwan (written in Chinese). Retrieved from http://news.secr.ncku.edu.tw/files/15-1054-78624,c9485-1.php?Lang=zh-tw

Chen, C. I., \& Chen, H. R. (2013). Refute to CEO Kuo's “wasting social resource” talk, selling fried chicken chop could also be the best in the field (written in Chinese). Retrieved from http://city.udn.com/55272/4936121

Chen, I. S. (2010). Crisis in higher education: My university is shutting down (written in Chinese). Commonwealth, $444 . \quad$ Retrieved from https:/www.ptt.cc/man/Criminal_law/DD35/M.1286712832.A.89E.html

Chen, Y. C., \& Wang, T. L. (2015). Zero Enrolment at Doctoral Programs-Top Universities Plan to Decrease Number of Doctoral $\quad$ Programs. Retrieved from http://udn.com/news/story/6885/644568-\%E5\%8D\%9A\%E5\%A3\%AB\%E7\%8F\%AD\%E8\%A8\%BB\%E5 $\% 86 \% 8 \mathrm{~A} \% \mathrm{E} 7 \% 8 \mathrm{E} \% 87 \% \mathrm{E} 6 \% 8 \mathrm{E} \% 9 \mathrm{~B} \% \mathrm{E} \%$ \% $8 \% 9 \mathrm{~B} \% \mathrm{E} 6 \% 8 \mathrm{~B} \% 9 \mathrm{~B}$

Council of Graduate Schools. (2007). Data sources: Trends in new PhDs entering academe, 1970 to 2005 . CGS Communing Education Newsletter, 40(2:4).

Council of Graduate Schools. (2008). Graduate education and the public good-Report for council of graduate schools. Washington DC: Council of Graduate Schools.

Dolado, J. J., Felgueroso, F., \& Jimeno, J. F. (2000). Youth labour markets in Spain: Education training, and crowding-out. European Economic Review, 44, 943-956. http://dx.doi.org/10.1016/S0014-2921(99)00050-1

Eggins, H. (Ed.). (2010). Access and Equity. In Comparative Perspectives. Sense Publishers.

Enders, J. (2004). Research training and careers in transition: A European perspective on the many faces of the PhD. Studies in Continuing Education, 26, 419-429. http://dx.doi.org/10.1080/0158037042000265935

Executive, Y. (2015). Manpower Survey Results in Jan 2015. Retrieved from http://win.dgbas.gov.tw/dgbas04/bc4/timeser/comuse_f.asp

Giret, J. (2005). The theory of employment: The professional debut young PhDs. Marseilles: Centre for Studies and Research on Qualifications. 
Guri-Rosenblit, S., Sebkova, H., \& Teichler, U. (2007). Massification and deiversity of higher education systems: Interplay of complex dimensions. Retrieved from http://unesdoc.unesco.org/images/0015/001578/157816e.pdf

Hales, C., \& Mowbray, S. (2011). The impact of the doctorate. Studies in Higher Education, 5(36), 513-525. http://dx.doi.org/10.1080/03075079.2011.594590

Han, G. D., \& Lin, C. C. (2007). Can't get a job, many PhDs stay at home (written in Chinese). Retrieved from http://city.udn.com/55272/2392138

Haynes, K., Metcalfe, J., \& Videler, T. (2009). What do researchers do? First destinations of doctoral graduates by subject. London: Careers Research and Advisory Centre.

Huang, C. S. (2010). Is it just a dream? Discussion about the difficulties PhDs from the field of Chinese Literature (written in Chinese). Chinese World, 26(3), 12-17.

Karaim, R. (2011). Expanding higher education. CQ Global Researcher, 5, 525-572. Retrieved from http://library.cqpress.com/

King, D. (2008). Doctoral graduates in Canada: Findings from the survey of earned doctorates, 2004/2005. Ottawa: Minister of Industry. Statistics Canada.

Larkin, J., \& Neumann, R. (2009a). University career management practices for academic staff. New Zealand Journal of Human Resource Management, 9(2), 120-130.

Larkin, J., \& Neumann, R. (2009b). Older academics and career management: An interdisciplinary discussion. Australian Journal of Career Development, 18(3), 29-39. http://dx.doi.org/10.1177/103841620901800305

Lin, C. C. (2009). If I knew I would just get a part-time job, I wouldn't pursue PhD in the beginning (written in Chinese). Retrieved from http://blog.yam.com/cy2000/article/25145225

Mayhew, K., Deer, C., \& Dua, M. (2004). The move to mass higher education in the UK: Many questions and some answers. Oxford Review of Education, 30(1), 65-82. http://dx.doi.org/10.1080/0305498042000190069

MOE. (2013). Yearbook of teacher education statistics. Retrieved from http://www.edu.tw/FileUpload/1052-25302\%5CDocuments/102YEARBOOK.pdf

MOE. (2014). Teacher Education Act. Retrieved from http://law.moj.gov.tw/Eng/LawClass/ LawContent.aspx?PCODE $=\mathrm{H} 0050001$

MOE. (2015). Survey on number of enrolled students and schools at each education level (written in Chinese). Retrieved from http://www.edu.tw/pages/detail.aspx?Node=4075\&Page=20046\&Index $=5 \& \mathrm{WID}=31 \mathrm{~d}$ 75a44-efff-4c44-a075-15a9eb7aecdf

MOE Department of Statistics. (2014). The growing condition at higher education level. Retrieved from https://stats.moe.gov.tw/files/brief/\%E5\%A4\%A7\%E5\%B0\%88\%E6\%A0\%A1\%E

B3\%BB\%E6\%89\%80\%Е5\%8F\%8A\%E5\%AD\%B8\%E7\%94\%9F\%E4\%BA\%BA\%E6\%95\%B8\%Е6\%88 $\% 90 \% \mathrm{E} 9 \% 95 \% \mathrm{~B} 7 \% \mathrm{E} 6 \% \mathrm{~A} 6 \% 82 \% \mathrm{E} 6 \% \mathrm{~B} 3 \% 81$.pdf

MOE Department of Statistics. (2015). Student enrollment data at higher education institutions. Retrieved from http://stats.moe.gov.tw/enrollweb

Nerad, M. (2004). The PhD in the US: Criticisms, facts, and remedies. Higher Education Policy, 17, 183-199. http://dx.doi.org/10.1057/palgrave.hep.8300050

Nerad, M. (2009). Confronting common assumptions: Designing future-oriented doctoral education. In R. G. Ehrenberg, \& C. V. Kuh (Eds.), Doctoral education and the faculty of the future (pp. 80-89). Ithaca, NY: Cornell University Press.

Neumann, R., \& Tan, K. (2011). From PhD to initial employment: The doctorate in a knowledge economy. Studies in Higher Education, 36(5), 601-614. http://dx.doi.org/10.1080/03075079.2011.594596

Neumann, R. (2003). The doctoral education experience. Science and Training. Canberra: Australian Government Publishing Service.

Neumann, R. (2006). Quality assurance and the strategic strengthening of HDR performance. In M. Kiley, \& G. Mullins (Eds.), Quality in postgraduate research: Knowledge creation in testing times (pp. 149-155). Canberra: Centre for Educational Development \& Academic Methods, the Australian National University.

Neumann, R., Kiley, M., \& Mullins, G. (2008). Australian doctoral graduates: Where are they going? In M. Kiley, 
\& G. Mullins (Eds.), Quality in postgraduate research in the new global environment (pp. 84-89). Canberra: Centre for Educational Development \& Academic Methods, the Australian National University.

Next Magazine. (2013). Survey on job market, 2013: PhDs face difficulties to find positions (written in Chinese). Next magazine, 8(1), 38-43.

NPHRST statistics database. (2014). Retrieved from http://hrst.stpi.narl.org.tw/html/2014_ NPHRST_employment_report.pdf

OECD. (2008). Education at a Glance 2014. Retrieved from http://www.oecd.org/education/skills-beyond-school/41284038.pdf

OECD. (2014). Education at a Glance 2014: OECD Indicators. http://dx.doi.org/10.1787/eag-2014-en

Paul, J., \& Perret, C. (1999). PhD graduates in France: Training, careers, and policy issues. In O. Kivinen, S. Ahola, \& P. Kaipainen (Eds.), Towards the European model of postgraduate training (pp. 157-186). Turku: Research Unit for the Sociology of Education.

Rudd, E., Nerad, M., Morrison, E., \& Picciano, J. (2008). Professional development for PhD students: Do they really need it? In CIRGE spotlight on doctoral education. Seattle: Centre for Innovation and Research in Graduate Education. University of Washington.

Schofer, E., \& Meyer, J. (2005). The worldwide expansion of higher education in the twentieth century. American Sociological Review, 70(6), 898-920. http://dx.doi.org/10.1177/000312240507000602

Smith, A. (2010). One step beyond: Making the most of postgraduate education. Retrieved from http://www2.le.ac.uk/departments/gradschool/about/external/publications/one-step.pdf

Smolentseva, A. (2012). Access to higher education in the post-Soviet States: Between Soviet legacy and global challenges. Retrieved from http://www.salzburgglobal.org/fileadmin/user_upload/ Documents/2010-2019/2012/495/Session_Document_AccesstoHigher Education_495.pdf

Thomson, P., \& Walker, M. (2010). The changing nature of the doctorate and doctoral students. The Routledge doctoral student's companion, 9-26.

Tomlinson, M. (2008). The degree is not enough: Students' perceptions of the role of higher education credentials for graduate work and employability. British Journal of Sociology of Education, 29(1), 49-61. http://dx.doi.org/10.1080/01425690701737457

Trow, M. (1973). Problems in the Transition from Elite to Mass Higher Education. Carnegie Commission on Higher Education.

Trow, M. (1974). Problems in the transition from elite to mass higher education. Policies for Higher Education, $51-101$.

Trow, M. (2006). Reflections on the Transition from Elite to Mass to Universal Access: Forms and Phases of Higher Education in Modern Societies since WWII. In P. Altbach, \& J. Forest (Eds.), International Handbook of Higher Education (pp. 243-280). Dordrecht: Springer.

Tssdnews. (2013). Editorial: How can government give up doing talented cultivation? (written in Chinese). Retrieved from https://tw.news.yahoo.com/\%E7\%A4\%BE\%E8\%AB\%96-\%E6\%94\%BF\%E5\%BA\% 9C\%E5\%B0\%8D\%E4\%BA\%BA\%E6\%89\%8D\%E8\%A6\%8F\%E5\%8A\%83\%E8\%B1\%88\%E8\%83\%BD \%E6\%9D\%9F\%E6\%89\%8B\%E7\%84\%A1\%E7\%AD\%96-16 1758397.html

UDN. (2015). The college enrollment numbers decreased 35\%, PhD programs will be reduced student numbers (written in Chinese). Retrieved from http://www.cna.com.tw/news/firstnews/201501150243-1.aspx

UNESCO. (2014). Higher education in Asia: Expanding out, expanding up. Retrieved from http://www.uis.unesco.org/Library/Documents/higher-education-asia-graduate-university-research-2014-en. pdf

Wang, T. C. (2012). Taiwan will experience talent fault soon. Retrieved from http://www.nownews.com/n/2012/08/07/170049

$\mathrm{Wu}, \mathrm{C}$. (2011). High graduate unemployment rate and Taiwanese undergraduate education. International Journal of Educational Development, 31, 303-310. http://dx.doi.org/10.1016/j.jjedudev.2010.06.010 


\section{Notes}

Note 1. Foreign PhDs refer to those receive their PhD degrees from abroad, compared to local PhDs, who receive their $\mathrm{PhD}$ degrees from program within Taiwan.

Note 2. The 23 programs are at the National Hsinchu University of Education, National Pingtung University, National University of Tainan, National Chungcheng University, National Chiayi University, National Changhua University of Education, National Kaohsiung Normal University, National Chengchi University, National Taiwan Normal University, National Taitung University, National Chengkung University, National Chiaotung University, National Sun Yat-Sen University, University of Taipei, National Taipei University of Education, National Taichung University of Education, National Central University, National Chi Nan University, National Taipei University of Technology, National Dong Hwa University, and National Yunlin University of Science and Technology.

\section{Copyrights}

Copyright for this article is retained by the author(s), with first publication rights granted to the journal.

This is an open-access article distributed under the terms and conditions of the Creative Commons Attribution license (http://creativecommons.org/licenses/by/3.0/). 